\title{
Sosyal Belediyecilik Bağlamında Yaşlı Bakım ve Alzheimer Gündüz Yaşam Merkezleri
}

\section{Elderly Care and Alzheimer's Day Care Centers in the Context of Social Municipality}

\author{
Muhammed Şener (iD) ${ }^{1}$, Hasan Hüseyin Tekin (iD) ${ }^{2}$
}

${ }^{1}$ Necmettin Erbakan Üniversitesi, Sağlık Bilimleri Enstitüsü, Sosyal Hizmet Anabilim Dalı, Konya, Türkiye
${ }^{2}$ Necmettin Erbakan Üniversitesi, Sağlık Bilimleri Fakültesi, Sosyal Hizmet Bölümü, Konya, Türkiye

Günümüzde, gelişmiş ve gelişmekte olan ülkelerde çeşitli sosyal politikaların yürütülmesinde merkezi yönetimler kadar yerel yönetimlerin de sorumluluk sahibi oldukları söylenebilir. $\mathrm{Bu}$ sorumluluk kapsamında belediyeler dezavantajlı gruplar başta olmak üzere sinırları içerisinde ikamet eden tüm vatandaşlarını gözeten sosyal politikalar geliştirmek ve bu politikalarla ilgili hizmetleri sunmak durumundadırlar. Yaşlılık sorunu ülkemiz dâhil tüm dünyanın gelecekteki en önemli sorunlarından biri olarak görülmektedir. Yaşlanan dünyada yaşlı nüfusun bakımı giderek önem kazanan ve çözüm bekleyen bir sosyal sorun haline gelmiştir. Ayrıca yaşlı nüfusunun artışıla orantılı bir şekilde artan Alzheimer hastalığ1 da üzerinde durulması gereken önemli bir sorundur. Yaşlıların ve Alzheimer hastalarının gündelik ihtiyaçlarının giderilerek sosyalleşme gereksinimlerinin sağlanacağ gündüzlü kuruluşların varlı̆ğ ve bu kuruluşların sosyal belediyecilik anlayışı çerçevesinde hizmet vermeleri yaşlılık sorunun etkilerinin azaltılması ve Alzheimer hastalı̆̆ yaşlıların tedavi süreçlerine katkı sağlanması açısından önemlidir. Bu çalışmanın amacı yaşlı bakım ve Alzheimer gündüz yaşam merkezlerinin önemini ve gerekliliğini sosyal belediyecilik ilkesi doğrultusunda ortaya koymaktır.

Anahtar kelimeler: Sosyal belediyecilik, yaşlı, Alzheimer gündüz bakım merkezi, Alzheimer hastalığı
Nowadays, it can be said that central and local governments are responsible for the implementation of various social policies in developed and developing countries. Within the scope of this responsibility, municipalities have to create social policies and provide services related to all citizens living with in their borders, especially disadvantaged groups. In the aging world, the care of the elderly population has become an increasingly important social problem. The existence of daytime institutions in which elderly people and patients with Alzheimer disease will be met by meeting their daily needs and providing services with in the framework of social municipality understanding is important in terms of reducing the effects of old age problem and contributing to treatment processes of elderly people with Alzheimer's. The aim of this study is to reveal the importance and necessity of elderly care and Alzheimer's day care centers in line with the principle of the social municipality.

Keywords: Social municipality, elderly, Alzheimer's day care center, Alzheimer's disease

\footnotetext{
Sorumlu Yazar / Corresponding Author: Muhammed Şener (iD)

E-posta / E-mail: muhammed.sener@ogr.konya.edu.tr

Adres / Address: Necmettin Erbakan Üniversitesi, Sağlık Bilimleri Enstitüsü, Sosyal Hizmet Bölümü, Meram, Konya, Türkiye

Telefon / Phone: +90 5454681713

Geliş Tarihi / Received: 14.05.2020 Kabul Tarihi / Accepted: 10.12.2020
} 


\section{GİRiş}

Sosyal belediyecilik; bütçesini eğitim, sağlık, kültür gibi faaliyetlere aktaran, işsizlikle mücadelede politikalar geliştirerek onları uygulamaya sokan, muhtaç bireylere ulaşarak onların korunmasını ve maddi açıdan desteklenmesini sağlayan, yerel çerçevede çeşitli sağlık ve eğitim olanaklarının geliştirilmesine katkı sunan ve sosyal adaletin tesis edilmesinde çeşitli kamu kurumlarına yardımeı olan bir modeldir (1). Sosyal hizmet belediyeciliği, neo-liberalizmle birlikte gelişen yeni kamu yönetimi anlayışı içinde belediyelerin sosyal sorunlara eğilimini benimseyen ve toplumsal işlevlerini geliştiren bir düşüncedir (2). Alzheimer hastalığ (AH) hafiza, öğrenme, karar verme, iletişim kurma ve kişinin günlük işlevleri yerine getirme noktasında yeteneklerini yavaş yavaş kaybeden ilerleyici ve yıkıcı bir beyin hastalığıdır. Hastalık 1906 yılında Dr. Alois Alzheimer tarafından özellikle yaşlı bireylerde görülen demansın bir türü olarak keşfedilmiştir (3). Hastalığın kesin tedavisi bulunmamakla birlikte semptomları yavaşlatıcı çeşitli tedavi yöntemleri bulunmaktadır. Özellikle uzun süreli bakım yöntemleri hem hasta için hem de hastaya bakmakla yükümlü olan aile bireyleri için oldukça fayda sağlamaktadır. Yalnız ülkemizde gündüzlü yaşam merkezleri ve huzurevleri yeteri derecede gelişmemektedir (4). Sosyal belediyecilik anlayışı çerçevesinde bu tarz gündüz yaşam merkezlerinin sayısının artması gerekmektedir. Bu çalışma gündüzlü yaşam merkezleri modelini temel alan yaşlı gündüz bakım ve Alzheimer gündüz bakım merkezlerinin gerekliliğini sosyal belediyecilik kapsamında ortaya koymayı amaçlamaktadır.

\section{Yaşlı ve Yaşlılık}

Yaşlı birey yaşlanmayla beraber ortaya çıkan sorunlarla baş etme noktasında fizyolojik olarak güçsüz düşmekte ve bunun sonucunda hastalıklarla karşılaşma olasılığı artmaktadır (5). Bu süreçte yaşlı bireylerde en sık görülen hastalıkları şu şekilde sıralayabiliriz: kalp- damar sistemi hastalıklan, kronik akciğer hastalığı, kas-iskelet sistemi hastalıkları, şeker hastalığı, hipertansiyon, AH, Parkinson hastalığı gibi hastalıklardır (6).

Yaşlı1ığın standart bir tanımı olmamasına rağmen biyolojik, psikolojik, sosyolojik ve ekonomik alanda 4 ayrı tanımı bulunmaktadır. Biyolojik yaşlanma; gelişim evreleri gereği vücut yapısının ve çeşitli organların işlevinin değişmesidir. Bu değişim sürecinde en erken yaşlanan hücre gözümüzde bulunan lens hücreleridir (7). Psikolojik yaşlanma; kişinin, zekâ, öğrenme, dikkat, dil, bellek, ak1l yürütme, görsel yetiler vb. bilişsel işlevlerinde değişikliklerle beraber kişilik ve duygularında ortaya çıkmaya başlayan değişimlerle ilgilidir (8). Sosyolojik anlamda yaşlanma ise; bireyin toplumsal anlamda içinde bulunduğu durumun gerekliliği olarak edindiği rol, statü ve beklentilerinin değişmesi olarak nitelendirilmektedir. Dünya Sağlık Örgütü (DSÖ) ise kronolojik tanımlamayı dikkate alarak yaşlanmayı 65 yaş ve üzeri bireyler şeklinde kabul etmektedir (9).

Türkiye İstatistik Kurumu (TUIKK) verilerine göre ülkemizin 2018 y1lı nüfusu 82 milyon civarındadır ve bu sayının yaklaşık 7 milyonunu 65 yaş üstü bireyler oluşturmaktadır. 65 yaş ve üstü nüfusun tüm nüfusa oranı $\% 8,8$ 'i uluştururken (10), bu oranın 2050 y1lında $\% 20,8$ 'e ve 2075 y1lında ise $\% 27,7$ 'ye ulaşacağı tahmin edilmektedir (11).

Yaşlılık bütün yönleriyle kayıplar dönemi olarak adlandırılabilir ve oldukça yıpratıcı bir süreçtir. $\mathrm{Bu}$ süreçte yaşlı bireylerin hayatlarını zora sokan dış etmenlere bağlı problemlerin yaşanması birçok sorunu beraberinde getirmektedir. En çok yaşanan sorunları şu şekilde sıralayabiliriz: ekonomik sorunlar, sosyal sorunlar, sağlık sorunları, bakım sorunu, konut sorunu ve psikolojik sorunlar şeklindedir (12).

Bakım ihtiyacı hisseden yaşlı birey, günlük aktivitelerini yerine getirme noktasında başka birinin fiziki yardımı gereklidir. Bunun 
sonucunda bakıma muhtaç birey, bedensel hareketlerinin kısitlanması sonucunda öz bakımını gerçekleştirebilmek adına evde veya kurumda bakıcılar tarafindan sürekli bakıma ihtiyaç duymaktadır (13).

\section{Alzheimer Hastalığ}

$\mathrm{AH}$, hafızayı ve düşünme becerilerini ve en basit işleri yapma yeteneğini yavaş̧̧a yok eden, geri dönüşü olmayan, ilerleyen bir beyin hastalığıdır. Hastalığa sahip olan bireylerin çoğunda belirtiler ilk olarak 60'lı yaşların ortalarında görülür. $\mathrm{AH}$, yaşlı bireylerde en s1k rastlanan demans (bunama) çeşididir (14). Demans, zihinsel aktivitelerin tahribatı sonucu bireyin günlük becerisindeki işlevselliğin bozulması ile karakterize bir hastalıktır. Oryantasyon, dikkat, bellek, görsel mekânsal işlevler, dil, apraksi ve yürütücü işlevler gibi bilişsel işlevlerin en az ikisinin etkilenmesi demans tanısının konulması için yeterlidir (15). $\mathrm{AH}$, demansın en yaygın nedeni olup çoğu demans olgusunun \%60-70'ini oluşturan bir hastalıktır (16).

$\mathrm{AH}$ için yapılan bir başka tanımda ise $\mathrm{AH}$, merkezi sinir sisteminin belirli bölgelerinde nöron ve sinaps kayıplarıyla ortaya çıkan; bilişsel fonksiyonlarda azalma, öz bakım yetersizlikleri, çeşitli davranış ve psikiyatrik bozukluklar ile birlikte görülen ilerleyici bir nörodejeneratif bir hastalıktır (17). $\mathrm{AH}$ görülme sıklığı 65 yaş üzerinde \%6-10 iken bu say1 85 yaş ve üzeri bireylerde \%30-47'dir. Bir başka görülme sıklığı çalışmasında ise ülkemizde 350-400 bin kişinin $\mathrm{AH}$ olduğu düşünülmektedir (18). Yaş, cinsiyet, aile geçmişi ve kalıtım, eğitim düzeyi, kafa travmas1, Down sendromu, hipertansiyon, diyabet, depresyon, , alkol ve sigara kullanımı gibi faktörler $\mathrm{AH}$ için risk faktörü olarak belirtilmektedir (19).

\section{AH'nın Evreleri}

$\mathrm{AH}$, kademeli olarak ilerleyen bir hastalıktır. Hastalığın, erken, orta ve ileri evre olmak üzere üç seyir evresi vardır.

\section{Erken Evre}

Hastalığın başlangıç belirtileri çok net olmamakla birlikte hastalığın ne zaman başladığ $\breve{1}_{1}$ da kesin olarak bilinememektedir. Eşyaları kaybetme, kısa sürede edinilen bilgiyi hafizada tutamama, bilmediği bir yerde ise yön bulmada güçlük, kelime bulmada güçlük, yeni beceriler öğrenememe, umursamazlık, üzüntü hali ve hastalığı inkâr etme AH'nın ilk evrelerinde görülen belirtilerdir (20). Bu evredeki hasta birey bazı ihtiyaçlarını kendisi yerine getirebilir. Banyo, tuvalet, giyinme gibi günlük işlevlerini yapmaya devam edebilir fakat süreç ilerledikçe yaptığı işin kalitesinde düşüşler meydana gelmektedir (21).

\section{Orta Evre}

$\mathrm{Bu}$ evrede hasta bireyin günlük yaşam aktivitelerini yerine getirme noktasında yaşamaya başladığı sorunlar gün yüzüne çıkmaya başlamaktadır. Yardım edilmesine rağmen yemede güçlük, arkadaşlarını veya aile üyelerini tanımada güçlük, farkında olmadan idrar ve gaita kaçırma, yürüme ve bazı motor fonksiyonlarında azalma ve belli başlı davranış bozuklukları bu evrede görülmeye başlanmaktadır (22). Hasta birey bu evrede bir yakının gözetimiyle dışarı çıkabilir ama yalnız kalması sonucu yolunu bulamaz. Yeni bilgileri öğrenme neredeyse imkânsız bir hal almaktadır. Birinci derecede yakını hakkındaki bilgileri hala hatırlayabiliyor olsa da torunlarının sayısını, isimlerini veya hangi okulda okuduklarını karıştırmaktadır. Davranışsal problemler ön plana çıkmaya başlar. Hırsızlık ve terk edilme gibi çeşitli hezeyanlar görülmektedir (23). 


\section{İleri Evre}

$\mathrm{Bu}$ evre hastanın düşünme yetisini tamamen kaybettiği, kişilik özelliklerinin değiştiği ve günlük yaşam aktivitelerini bir başkası olmadan hiçbir şekilde yerine getiremediği son evredir (24). Hezeyanlar, ajitasyon ve halüsinasyonlar artar, hareketlilik yok denecek kadar azalır, iletişim kurmak güçleşir ve konuşmaları cümlelerin veya kelimelerin tekrarından öteye gidemez. Günlük yaşam aktivitelerinin gerçekleşebilmesi adına gerekli yardım sağlanmalı, hasta birey sürekli bakıma gereksinim duyuyor ise kurum bakımı sağlanmalı veya bu kurum bakımı sağlanamadığı takdirde evde bakım için uygun şartların sağlanması gerekir (25). İleri evre zordur ve hastanın çoğu yaşamsal fonksiyonlarında bozukluklar meydana gelmektedir. Neredeyse hiç konuşmaz. Son evrede yatalak bir hal aldığ 1 için hasta bireyin bakımı da gittikçe güçleşir. $\mathrm{Bu}$ son evreden sonra hasta vefat eder (26).

\section{Yaşlılara Sunulan Hizmetler}

1983 tarih ve 2828 sayı ile kabul edilerek yürürlüğe giren "Sosyal Hizmetler ve Çocuk Esirgeme Kurumu Kanunu" sosyal hizmetlerin ülkemizde hukuken tanımlanmasını sağlamıştır. Sosyal hizmetler bu kanunun 3 . maddesi a bendinde: "kişi ve ailelerin kendi bünye ve çevre şartlarından doğan veya kontrolleri dışında oluşan maddi, manevi ve sosyal yoksunluklarının giderilmesine ve ihtiyaçlarının karşılanmasına, sosyal sorunlarının önlenmesi ve çözümlenmesine yardımcı olunmasını ve hayat standartlarının iyileştirilmesi ve yükseltilmesini amaçlayan sistemli ve programlı hizmetler bütününü şeklinde tanımlanmaktadır” (27). Birleşmiş Milletler yaşlılara sunulan hizmetlerde ağırlıklı olarak devletin sorumluluk üstlenmesi gerektiğini ifade etmektedir (28). Gökkoca ve Baharlıetik (29) yaşlılara verilen hizmetlerin 3 ana amacı olduğunu belirtmektedir; a. Kendi evlerinde mümkün oldukça bağımsız, mutlu ve rahat bir yaşam sürmelerini sağlamak,

b. Yaşlanmayla gelen fiziksel ya da mental hastalıklar için gerekli olan uygun hastane imkânlarını sağlamak,

c. Yaşlılık, evsizlik ve bakım ihtiyacı gibi durumlarda alternatif yerleşim olanaklarını sağlamak.

\section{Yaşlı Bakım Hizmetleri}

Yaşlılara yönelik bakım hizmetleri ikiye ayrılmaktadır; evde bakım ve kurum bakım hizmetleri. Artan yaşlı nüfusla beraber ülke genelinde evde bakım hizmetlerine duyulan gereksinim giderek artmaktadır. Evde bakıma muhtaç olan yaşlı bireye evde bakım verilmesi hem hastane işleyişini rahatlatacak hem de ülke ekonomisine olan mali yükü hafifletecektir. Evde bakım sonucunda yaşlı bireyin bedensel sağlı̆̆ bağımlılık düzeyi ile entelektüel gelişimi olumlu şekilde etkilenecektir (30).

Kurum bakımı ise ülkemizde yaşlı bakım ve rehabilitasyon merkezleri ile huzurevleri tarafından verilmektedir. Yaşlı bakım ve rehabilitasyon merkezlerinde uzun süreli olarak yaşlının kişisel ve sosyal bakımı yapılmaktadır. Çoğu günlük yaşam aktivitelerini yerine getirirken bir başkasının yardımına ihtiyaç duymaktadır (28). Huzurevleri ise, ekonomik gücü ve kendisine bakacak gücü olmayan kimsesiz yaşlilara ücretsiz; ekonomik gücü yerinde olup kendisine de bakabilen yaşlılara ücretli şekilde hizmet veren kurumlardır. Ülkemizde 2015 y1l itibariyle genel nüfusun $\% 1,5$ 'i evde bakım hizmetlerinden faydalanmaktadır (31) (Tablo I). 
Tablo I. Türkiye'de 60 Yaş ve Üzeri Nüfusta Kurumsal Bakım Hizmeti ve Evde Bakım Ücreti Desteği Alanların Oranı

\begin{tabular}{lcc}
\hline & Sayı & Yüzde (\%) \\
$\begin{array}{l}\text { 60 Yaş ve Üzeri } \\
\text { Toplam Nüfus }\end{array}$ & 9.603 .706 & 100 \\
$\begin{array}{l}\text { Kurumsal Bakım } \\
\text { Hizmeti Kalitesi } \\
\text { (resmi ve özel) }\end{array}$ & 28.433 & 0.3 \\
$\begin{array}{l}\text { AÇSHB } \\
\text { Huzurevlerinde } \\
\text { Kalanlar }\end{array}$ & 12.299 & 0.1 \\
$\begin{array}{l}\text { Evde Bakım Ücreti } \\
\text { Desteği Alanlar }\end{array}$ & 156.000 & 1.6 \\
\hline
\end{tabular}

Kaynak: ASPB EYHGM İç Raporları, 2015

\section{Yaşlılara Yönelik Gündüz Bakım Hizmetleri}

Gündüz yaşam merkezleri (GYM), yaşl1 bireyler için toplumun da katılımını sağlayan planlı etkinlikleri kapsayarak sağlıklı bir yaşam sürmelerini amaçlayan bir modeldir. Yaşlının sosyal yönden kendini iyi hissetmesine katkı sunan ve başkasına bağımlı kalmadan yaşamasını hedefleyen süreli bakım hizmetlerini içermektedir. GYM'ler, genellikle sağlık sorunu olan yaşlı bireyler için tıbbi ve psiko-sosyal yardımı içeren hizmetleri kapsar (12). GYM'ler yaşlının erkenden ve gereksiz yere kurum bakımına alınmasını önlemeyi amaçlamaktadır. Bu çerçevede yaşlı bireyi içinde bulunduğu sosyal ortamdan koparmadan boş zamanlarını daha verimli şekilde değerlendirebilmesi için onların özsaygılarını güçlendirerek kendilerini daha iyi hissetmelerini sağlamaktadır (31).

GYM aşağıdaki faaliyetleri yürütmektedir (34):

a. Yaşl1ların motor becerilerini koruyacak ve artıracak çeşitli etkinliklerden oluşan meşguliyet terapilerinin yapılması,

b. Yaşlıların beden sağlıkları için gerekli olan fizik tedavi egzersizleri ile günlük hafiza çalıştırma egzersizlerinin yapılması,

c. Yaşlı sağlığ 1 için önemli olan dinlenme ve uygu zamanlarının planlanması, d. Yaşlıların rutin sağlık taramalarının yapılarak, ilaç ve tansiyonlarının takip edilmesi,

e. Yaşlıların ailelerin kurum sürecine ilişkin oryantasyonlarının yapılması.

\section{AH Tedavisinde Kurum Bakımı}

AH'nın bugün için kesin tedavisi yoktur. Mevcut tedaviler var olan hastalığın seyrini biraz olsun yavaşlatmaya yönelik tedavilerdir (32). AH birincil tedavi yöntemi, hastalığın kognitif belirtilerine odaklanmış olup ilaçla yapılan tedavidir. İkincil tedavi ise; hastalığın seyrinde meydana gelen kayg1, ajitasyon, uyku bozukluğu, depresif belirtiler ve sanrı gibi semptomların giderilmesini amaç edinen ve bakım merkezli uygulamalardır (33). Ancak ülkemizde Alzheimer hastaları için yeterli sayıda huzurevi, gündüz hastanesi veya bakım merkezi bulunmamaktadır. Genellikle bu hastalar birinci derece yakınları tarafından evde bakılmaktadır ve bu kişiler çoğu zaman nelere dikkat etmeleri ve nasıl davranmaları gerektiğini bilmemektedir (34).

Kurum bakımına alternatif olarak üretilen bir hizmet modeli de gündüzlü bakım veren kurumlardır. $\mathrm{Bu}$ hizmet modeli Alzheimer hastaları için oldukça önemlidir. Alzheimer hastaları bu merkezlere gündüzleri gelerek sosyalleşebilirler. Böylece hastaların yaşam ortamları bir ev olmaktan çıkarak çeşitlenir, boş zamanları değerlendirilir. Merkezler Alzheimer hastasının yaşam kalitesini yükseltmek konusunda önemli bir güce sahiptir (35).

\section{AH Tedavisinde Gündüzlü Kurum Bakımı Örnekleri}

Ülkemizde AH ile mücadelede "Türkiye Alzheimer Derneği'nin" toplam 13 ilde dernekleştiği görülmektedir. Bu 13 il içerisinde yer alan 7 Gündüz Yaşam Merkezi (GYM), Alzheimer hastalarının keyifli ve kaliteli zaman geçirmelerini, Alzheimer hastalarına bakım veren kişilere bir nebze nefes aldırarak 
omuzlarındaki yüklerini biraz olsun hafifletmelerini amaç edinmektedir. Bu amaç doğrultusunda GYM'lerde çeşitli zihinsel, bedensel, sanatsal, müziksel, psikomotor aktivitelerle birlikte özel gün kutlamaları, gezi ve manevi destekli programlar yürütülmektedir (36).

\section{Sosyal Belediyecilik}

Günümüzde gelişmiş ve gelişmekte olan ülkelerde çeşitli sosyal politikaların yürütülmesinde merkezi yönetimler kadar yerel yönetimlerin de sorumluluk üstlenmeleri beklenir. Bundan dolay1 yerel yönetimlerin sosyal politika içerikli uygulamaları sosyal belediyecilik kavramı içerisinde yer almakta ve belediyeler, sosyal devlet anlayışının yereldeki temsilcileri konumuna gelmektedirler (1).

Sosyal belediyecilik; sosyal devletin vatandaşlarına sağlamakla yükümlü olduğu çeşitli sosyal politika ve faaliyetlere yerel yönetimlerinde katılıp sosyal refahın sağlanmasında sosyal yardım ve hizmetlerin yerine getirilmesi şeklinde ifade edilebilir (37). Başka bir tanımlamada ise sosyal belediyecilik; bütçesini eğitim, sağlık, kültür gibi faaliyetlere aktaran, işsizlikle mücadelede politikalar geliştirerek onları uygulamaya sokan, muhtaç bireylere ulaşarak onların korunmasını ve maddi açıdan desteklenmesini sağlayan, yerel çerçevede çeşitli sağlık ve eğitim olanaklarının geliştirilmesine katk1 sunan ve sosyal adaletin tesis edilmesinde çeşitli kamu kurumlarına yardımcı olan bir modeldir (1).

Alan yazında sosyal belediyecilik kavramiyla ilgili en sık kullanılan tanım Yalçın Akdoğan'ın sosyal belediyecilik tanımıdır. Bu tanıma göre "sosyal belediyecilik, yerel yönetimlere sosyal alanlarda planlama ve düzenleme işlevi yükleyen, bu çerçevede kamu harcamalarını konut, sağlık, eğitim ve çevrenin korunması alanlarını kapsayacak şekilde sosyal amaca kanalize eden; işsiz ve kimsesizlere yardım yapılması, sosyal dayanışma ve entegrasyonun tesis edilmesi ile sosyo-kültürel faaliyet ve çalışmaların gerçekleştirilebilmesi için gerekli olan altyapı yatırımlarının yapılması için bilinçli politikalar üretmesini öngören; bireyler ve toplumsal kesimler arasında zayıflayan sosyal güvenlik ve adalet mevhumunu güçlendirmeye yönelik olarak yerel yönetimlere sosyalleştirme ve sosyal kontrol işlevleri yükleyen bir modeldir" (38).

Artık günümüzde belediyeler yol, park, su, imar, alt yapı sorunları gibi fiziki çalışmalarla yetinmemektedir ve bunun sonucunda da belediyeler ekonomik ve sosyal alanlarda da çeşitli faaliyetler yürütmektedir (39). Belediyeler kendi sınırları içinde ikamet eden vatandaşların üç temel sorununa yönelik çeşitli politikaları gündemine almaktadır. $\mathrm{Bu}$ sorunlardan ilkini özellikle büyük kentlerde acil müdahale gerektiren dilencilik, işsizlik, yoksulluk oluştururken; ikincisini, belediyelerin kendisinin hizmet götürdüğü yerlerde çeşitli doğal afetler sonucu oluşan zararlardan etkilenen ailelerin sosyal problemleri oluşturur ve son olarak da insan yapısı gereği çevrenin de etkisiyle somutlaşan çocuk, yaşlı ve dezavantajlı bireylerin sorunlarını kapsamaktadır. Bahsedilen üç ana sorun sosyal belediyecilik anlayışı çerçevesinde belediyeler tarafindan sunulan sosyal yardımlar ve sosyal hizmetler tarafindan giderilmeye çalışılmaktadır (40).

\section{Sosyal Belediyecilik ve Sosyal Hizmet}

Sosyal hizmetler, toplum içerisinde elinde olmayan sebeplerden dolayı bedenen veya ruhen muhtaç duruma düşen bireylere, ülkenin içinde bulunduğu sosyal ve ekonomik şartlar gözetilerek çevresi ile uyumlu şekilde yaşamalarını sağlayan çeşitli sosyal politikalara denir (41).

Ülkemizde sosyal belediyecilik anlayışı çerçevesinde sunulan sosyal hizmetlerden daha çok çocuklar, engelliler, yaşlılar, gençler, kadınlar ve dar gelirler faydalanmaktadır. Yerel yönetimler, belirtilen kesimler için 
"Sağlık ve Sosyal Hizmetler", "Sağlık İşleri", "Eğitim ve Kültür İşleri" gibi isimlerle anılan hizmet birimlerini oluşturmaktadır (42).

Ülke nüfusunun giderek yaşlanmaya başladığ 1 şu dönemlerde belediyeler tarafindan yaşlıların çeşitli sosyal hizmetlerden faydalanması sağlanmaktadır. Sağlık yardımı, bulunduğu yere yönelik bazı mekânsal düzenlemeler, yiyecek, yakacak, gıda ve ulaşım gibi hizmetlerden yararlanabilmesi adına ayni ve nakdi yardımlar ve çeşitli sosyo-kültürel faaliyetlerin gerçekleştirilmesi sunulan hizmetlerin başlıcalarıdır (43).

Bunlara ek olarak; huzurevi hizmetleri, evde bakım hizmetleri, psiko-sosyal destek hizmetleri ve sosyal yaşam merkezleri gibi hizmetler de yaşlı bireylerin hizmetine sunulmaktadır. Yerel yönetimlerin yaşlılara sundukları hizmetler ülke genelinde standart bir hale gelmemiştir. Bazı belediyelerde evde bakım hizmetleri bulunmazken, bazılarında ise huzurevlerine rastlanmamaktadır (44).

Sosyal hizmetlerin vatandaşlara etkili ve verimli bir şekilde ulaşabilmesi noktasında sosyal hizmet uzmanları görev almaktadır. Sosyal hizmet uzmanı; sosyal, psikolojik ve ekonomik faktörlere dayalı olarak bireylerin ve ailelerin yaşadıkları sorunların üstesinden gelme ve çeşitli çözüm yolları bulma noktasında bireyleri kaynaklarla buluşturan, aldıkları eğitim ve edindikleri deneyimler sayesinde bireylerin ihtiyaçlarına en iyi cevabı verip onlara yardımc1 olan meslek elemanlarıdır (45). Bu kapsamda sosyal hizmet uzmanları tarafından verilen hizmetleri şu şekilde sıralayabiliriz (46):

a. T1bbi sosyal hizmetler ve psiko-sosyal danışmanlık hizmetleri,

b. Yaşl1lara bakım ile psiko-sosyal destek hizmetleri,

c. Bakıma muhtaç insanlar için kurumsal düzeyde bakım hizmetleri,

d. Alkol ve madde bağımlısı bireyler için rehabilitasyon hizmetleri, e. Evlilik öncesi ve evlilik sonrası süreçlerde aile danışmanlık hizmetleri,

f. Çocuk koruma ve kurumsal yetiştirme hizmetleri,

g. Tabii afetlerde mağdurlara psiko-sosyal ve ekonomik destek hizmetleri.

\section{Sosyal Belediyeciliğin Hukuki Dayanakları}

Ülkemizde sosyal belediyecilik faaliyetlerinin uygulanmaya başlanması özellikle 1980'li yıllardan sonra başlamıştır. 5393 sayılı Belediye Kanunu ile 5216 sayılı Büyükşehir Belediyesi Kanunu kapsamında yer alan birçok madde sosyal belediyeciliğin hukuki zeminini oluşturmaktadır. Bu iki kanun, belediyelerin çeşitli sosyal politikaları gerçekleştirmesinde geniş yetkiler vermiştir (47).

5216 sayılı Büyükşehir Belediyesi Kanunu, bireylerin sosyal ihtiyaçlarının karşılanması ve sosyal sorunlarının çözüme kavuşturulması görevini yerel yönetimlere bırakmaktadır. Aynı kanunun 7. maddesinde "gezici sağlı üniteleri ile yetişkinler, yaşlılar, engelliler, kadınlar, gençler ve çocuklara yönelik her türlü sosyal ve kültürel hizmetleri yürütmek, geliştirmek ve bu amaçla sosyal tesisler kurmak, meslek ve beceri kazandırma kurslanı açmak" sorumluluğunu vermektedir (48).

5393 sayılı Belediye Kanunu'nun 13. maddesinde, herkesin ikamet ettiği bölgenin hemşerisi olduğunu ve hemşerilerin belediye hizmetlerinden yararlanma hakkına sahip olduğu açık bir şekilde ifade edilmektedir. Ayrıca aynı madde de belediyeler, halk arasında sosyal ve kültürel faaliyetlerin geliştirilmesi için çeşitli kamu kurumları, sivil toplum örgütleri ve uzman kişilerden yardım alabilmektedir (49). Sosyal belediyecilik anlayışı çerçevesinde yürütülmesi gereken hizmetleri şu şekilde özetleyebiliriz (50);

a. Barınma gereksinimi olan kimsesiz vatandaşların (kadın, erkek, çocuk) barınma gereksinimlerini karşılamak, 
b. Çocuk gündüz bakımevleri ve kreşler yapmak,

c. Yaşlılar için gündüz bakım evleri ile huzurevleri yapmak,

d. Hastane ve sağlık kampüs alanları çevresine refakatçıların barınması için misafirhaneler yapmak,

e. Mahalle düzeyinde kültürel ve sanatsal etkinliklere imkân verecek merkezler açmak,

f. Dezavantajlı gruplarda yer alan ihtiyaç sahibi yoksullar için aşevleri ve imarethaneler kurmak,

g. Tanzim satış mağazaları ile halkın temel gıdası olan ekmek fabrikalarını kurmak,

h. Engelli vatandaşların sosyal yaşamlarını kolaylaştıracak düzenlemeleri yapmak,

i. Gençler ve ev hanımları başta olmak üzere ilgi duyan tüm vatandaşlar için meslek ve beceri kursları açmak,

j.Vatandaşların sosyal yaşamlarını zenginleştirecek piknik, park ve bahçe alanlarını yaygınlaştırmak,

k. İş kurmak isteyen vatandaşlara yönelik proje destekleme sistemini oluşturmak,

1. Gıda, kömür, ilaç, kırtasiye malzemesi gibi temel ihtiyaçları karşılamaya yönelik sosyal ayni yardımları yapmak.

\section{SONUÇ}

Giderek büyüyen yaşlı nüfus beraberinde yaşl11ı sorununu getirmiş ve yaşl11ıkla birlikte görülme sıklığı artan Alzheimer hastalarına bakım sorunu da çözüm üretilmesi gereken sosyal sorunlardan biri haline gelmiştir. $\mathrm{Bu}$ sosyal sorununun çözüm sürecinde en önemli sorumluluk başta aile ve topluma düşmektedir, ardından kurumsal yapıların sorumluluk almaları beklenmektedir. Mevcut beklenti doğrultusunda yerel ölçekte öncelikli olarak belediyelerin yaşlılara ve Alzheimer hastalarına yönelik politikalar ve hizmetler üretmeleri gerekmektedir. Sosyal belediyecilik kapsamında toplumun yaşlı ve yaşl1lıktan kaynaklı hastalığa sahip kesimine verilecek hizmetler toplum sağlığına yarar sağlayacaktır. Sonuç olarak, sosyal belediyecilik anlayışının yerel yönetimlerde hâkim kılınması ve bu anlayış doğrultusunda toplumun kültürel bir miras1 ve değeri olan yaşlı nüfusun gündelik yaşamlarından kopmadan, toplumdan da dışlanmadan varlığını sağlıklı bir şekilde sürdürebilmesi için belediyelerin hizmet vermekle yükümlü oldukları nüfusun ihtiyacını karşılayacak sayıda Alzheimer gündüz yaşam ve yaşlı bakım merkezlerini hizmete açmaları oldukça önemlidir.

\section{Çıkar Çatışması ve Fonlama}

Yazı için finansal destek alınmamıştır.

Yazarlar çıkar çatışması olmadığını belirtir.

\section{KAYNAKLAR}

1. Berkün S. Türkiye'de sosyal belediyecilik anlayışı. eŞarkiyat İlmi Araştırmalar Dergisi, 2017; 9: 582-598.

2. Şimşek G, Altun F. Sosyal Belediyecilikte Sosyal Hizmetlerin ve Sosyal Girişimci Faaliyetlerin Rolü. Sosyal Çalışma Dergisi, 2020; 4, 55-61.

3. Özer S, Kocaelli H, Yaltırık M. Alzheimer hastalı̆̆ı ve dental yaklaşım. Journal of Istanbul University Faculty of Dentistry Dergisi, 2012; 41, 31-38.

4. Aile ve Sosyal Politikalar Bakanlığı. Demans Bakım Modeli Raporu. Ankara, 2017.

5. Bilir N. Yaşlanan toplum. Sağlıklı Yaşlanma, 2005; 3, 2332.

6. Akça N, Taşçı S. 65 yaş üstü bireylere bakım verenlerin yaşadıkları sorunların belirlenmesi. Sağlı Bilimleri Dergisi, 2015; 14, 30-37.

7. Göka E, Aydemir Ç. Yaşlıya ve demanslı hastaya psikososyal yaklaşım. Demans Dizisi, 2000; 1, 5-26.

8. Yalılı A., Dönmez Ç. F., Kaptan G. Türkiye'de yaşlı bakım kurumlarına dair bir değerlendirme. Sağlık Bilimleri Yaşam Dergisi, 2016; 1, 30-39.

9. Türkiye İstatistik Kurumu (TUIK), 2018.

10. Zıplar Ü. Dünya'da ve Türiye'de yaşlılık hizmetleri. Çankırı Karatekin Üniversitesi Sosyal Bilimler Enstitüsü Dergisi, 2015; 6, 173-194.

11. Tereci D., Turan G., Kasa N., et al. Yaşlılık kavramına bir bakış. Ufkun Ötesi Bilim Dergisi, 2016; 16, 84-116.

12. Borglin G., Ulf J., Anna-Karin E., et al. Self-reported health complaints and their prediction of overall and health-related quality of life among elderly people. International Journal of Nursing Studies, 2005; 42, 147158 . 
13. https://www.nia.nih.gov/health/what-alzheimers-disease Erişim tarihi: 27.11.2019.

14. Hanağası H., Emre M. Demans kavramı ve hastaya yaklaşım. Turkiye Klinikleri Neurology-Special Topics, 2009; 2, 1-4.

15. Akdemir A, Cangöz B, Örsel S, et al. Hafif kognitif bozukluğu olan hastalarla Alzheimer tipi demans hastalarının örtük bellek performansı açısından karşılaştırılması. Türk Psikiyatri Dergisi, 2007; 18, 118128.

16. Özkay Ü. D., Öztürk Y., Can Ö. D. Yaşlanan dünyanın hastalı̆̆ı: Alzheimer hastalığı. Süleyman Demirel Üniversitesi Tıp Fakültesi Dergisi, 2011; 18, 35-42.

17. Sarıkaya N., Sukut Ö., Ayhan C. H. Alzheimer hastalarında görülen davranışsal sorunları yönetme. G.O.P. Taksim E.A.H. JAREN, 2017; 3, 33-38.

18. Soner S., Aykut S. Alzheimer hastalık sürecinde bakım veren aile üyelerinin yaşadıkları güçlükler ve sosyal hizmet. Ahi Evran Üniversitesi Sosyal Bilimler Enstitüsü Dergisi, 2017; 3, 375-387.

19. Perkens P, Annegers JF. Doody RS. et al. Incidence and prevalance of dementia in a multiethnic cohort of retirees. Neurol 1997; 49: 44-50.

20. Tezcan S. Alzheimer hastalarına bakım veren kişilerin yaşadıkları güçlükler. İstanbul: Haliç Üniversitesi Sağlık Bilimleri Dergisi, 2017; 32-49.

21. Barlas G, Onan N. Alzheimer hastası ve aileleri ile iletişim. Atatürk Üniversitesi Hemşirelik Yüksekokulu Dergisi, 2008; 11, 105-111.

22. Selekler K, Alzheimer Nedir?. Editör: Selekler K, Alzheimer Orta Yaşta Başlar, 1. Baskı, İstanbul, Alfa Yayınları, 2012, 113-114.

23. Akyar İ, Akdemir N. Alzheimer hastalarına bakım verenlerin yaşadıkları güçlükler. Sağlık Bilimleri Fakültesi Hemşirelik Dergisi, 2009; 32-49.

24. Eker E. Alzheimer Hastalığı. İ.Ü. Cerrahpaşa Tıp Fakültesi Sürekli Tıp Eğitimi Etkinlikleri, 2008; 85-110.

25. Gürvit H, Baran B. Demanslar ve kognitif bozukluklarda ölçekler. Nöropiskiyatri Arşivi, 2007; 44, 58-65.

26. TC Resmi Gazete, 24 Mayıs 1983, Sayı: 18059.

27. Yerli G. Yaşlllık dönemi özellikler ve yaşlılara yönelik sosyal hizmetler. Uluslararası Sosyal Araştırmalar Dergisi, 2017; 10, 1279-1287.

28. Gökkoca Z. U., Baharlıetik N. Yaşlılık döneminde sosyal hizmet programları. H. Ü. Toplum Hekimliği Bülteni, 1999; 13, 19-58.

29. Bilge U, Elçioğlu Ö, Ünalacak M. Türkiye'de Yaşlı Evde Bakım Hizmetleri. Euras J Fam Med, 2014; 3, 1-8.

30. Karakuş B. Türkiye'de yaşlılara yönelik hizmetler, Editör: Dalkılıç Y. Türkiye'de yaşlılara yönelik hizmetler, kurumsal yaşlı bakım ve kurumsal yaşlı bakımda illerin durumu, 1.baskı, Ankara, Ertem Basım Yayın Dağıtım San. ve Tic. Ltd. Şti, 2018, 120-122.

31. Savaş S. Avrupa'da ve dünyada gündüz bakım evleri. 3. Akademik Geriatri Kongresi, 26-30 Mayıs 2010, Kaya Artemis Otel, Gazimağusa, KKTC, Sözlü Bildiri Kitapçı̆̆ı 132-136.
32. Selekler K, Editör: Selekler K, Alzheimer ve Diğer Demanslar 1. Bask1, Ankara, Güneş Kitabevi, 2003, 81-82.

33. Kulaksızoğlu I., Yücel N. Günlük Yaşam ve Aktiviteler, Editörler: Kulaksızoğlu I, Yücel N. Alzheimer hastası ile yaşamak, 1. Bask1. İstanbul, Novartis, 2010, 97-98.

34. Ateş, M. Yaşlı Bakım Hizmetleri, Editör: Ateş M, Sağlık Hizmetleri Yönetimi, 1. Bask1, İstanbul, Beta Basım Yayım Dağııım A.Ş., 2011, 242-244.

35. Nazlier Keser E, Alzheimer Hastalarına ve Bakım Verenlere Yönelik Sosyal Politikalar: Türkiye - Almanya Karşılaştırması. Sosyal ve Beşeri Bilimler Araştırmaları Dergisi, 2019; 20(45), 93-118.

36. https://www.alzheimerdernegi.org.tr Erişim Tarihi: 21.11.2019.

37. Çelik A. Sosyal belediyecilik anlayış: Şanlıurfa büyükşehir belediyesi örneği. Gazi Üniversitesi İktisadi ve İdari Bilimler Fakültesi Dergisi, 2014; 16, 1-20.

38. Akdoğan Y. Ulusal Soruna Yerel Çözüm: Sosyal Belediyecilik. Eminönü Bülteni, 2002, İstanbul.

39. Göymen K. Türkiye'de yerel yönetimler ve yönetişim: gereksinmeler, önermeler, yönelimler. Çağdaş Yerel Yönetimler Dergisi, 2000; 9(2), 3-13.

40. Ateş H. Sosyal Belediyecilik. Çerçeve Dergisi, 2009; 17, 88-95.

41. Ersöz H.Y. Doğuşundan Günümüze Sosyal Politika Anlayışı ve Sosyal Politika Kurumlarının Değișen Rolü. İstanbul Üniversitesi İktisat Fakültesi Mecmuas1, 2003; 53(2), 119-144.

42. Pektaş E. K. Türkiye'de sosyal belediyecilik uygulamaları ve temel sorunlar. Akademik İncelemeler Dergisi, 2010; 5, 4-22.

43. Sezik M. Türkiye'de sosyal belediyeciliğin gelişimi ve sorun alanları. İnönü Üniversitesi Uluslararası Sosyal Bilimler Dergisi, 2016; 5(2), 171-186.

44. Seçkiner Bingöl E., Ömürgönülșen U. Sosyal belediyecilik bağlamında Türkiye'de büyükşehir belediyelerinin sosyal hizmet ve sosyal yardım faaliyetleri. Çağdaş Yerel Yönetimler Dergisi, 2018; 27, 1-26.

45. Özer M. A. Sosyal ekonomi politikaları kapsamında sosyal belediyecilik anlayışı. Sosyal Politika Calışmaları Dergisi, $2015 ; 35,79-100$

46. Seyyar A. Sosyal Belediyecilik ve Sosyal Hizmetler, Editör Seyyar A. Sosyal politika bilimine giriş, 1. Baskı, Sakarya, Sakarya Yayıncilik, 2011, 215-217.

47. Sezik M. Büyükşehirlerin sosyal belediyecilik yaklaşımlarına bir örnek olarak madde bağımlılığı ile mücadele çalışmaları. Bitlis Eren Üniversitesi İktisadi Ve İdari Bilimler Fakültesi Akademik İzdüşüm Dergisi, 2017; 2, 51-63.

48. TC Resmi Gazete, 23 Temmuz 2004, Say1: 25531

49. TC Resmî Gazete, 3 Temmuz 2005, Sayı: 25874.

50. Öz C. S., Yıldırımalp S. Kent Yönetiminde Yeni Yaklaşımlar ve Etkin Belediyecilik Uygulamaları. Ed: Mecek M., Parlak B., Atasoy E. Nobel Yayıncılık, Ankara, 2018. 